\title{
Geminates and weight in Amharic
}

Hannah Sande and Andrew Hedding*

\section{LSA Annual Meeting, Minneapolis, January 2-5, 2014}

1. Introduction. Moraic Theory (Hayes 1989) predicts the existence of a language that classifies CVC syllables as light and syllables with a geminate coda (CVG) as heavy. Until now, no such language has been attested (Tranel 1991; Davis 2011). We propose that Amharic, a Semitic language spoken in Ethiopia, fits this pattern. Using data collected through eight months of fieldwork with two Amharic speakers, we demonstrate that two independent processes of the language, stress and reduplication, serve as evidence that geminate codas but not other codas are moraic in Amharic.

2. Phonological background of Amharic. To begin, we give a brief phonological overview of the language, focusing on those aspects relevant to the stress system and adjectival reduplication strategies. All consonants except $/ \mathrm{h} /$ have contrastive geminate alternates. Geminates in Amharic distinguish both lexical items and grammatical functions, though their main function is grammatical: [mäwäräd] 'to be embarrassed,' [mäwwäräd] 'to embarrass (someone else).' The largest possible syllable is $\mathrm{CCVC}(\mathrm{C})$, and it is especially relevant for our purposes to distinguish this from $\mathrm{CCVG}(\mathrm{G})$, where $\mathrm{G}$ stands for one half of a geminate consonant.

3. Amharic stress. The previous literature on Amharic stress is almost non-existent. Hudson (1997) says "Stress is not prominent in Amharic, [...] There is, however, little research on this topic." Leslau (2000) notes, "It is safe to state that the last syllable is not stressed," and "The syllable preceding a geminated syllable is likely to be stressed." This represents the first complete characterization of Amharic word-level stress.

3.1 THE BASIC STRESS PATTERN. The default stress pattern in Amharic involves binary, trochaic feet aligned to the left edge of a word. This stress pattern does not distinguish affixes from stems, but is concerned with each word as a whole. Stress has phonetic correlates of pitch and intensity; the stress pattern of a word is consistent within and across speakers.

1. Stress is not stem dependent

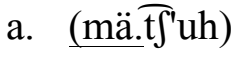
'to yell'
b. (โt'u.hät)
'a yell'
c. (ijj.jä).(t
'he is yelling'

\footnotetext{
* We would like to thank Claire Halpert and Daniel Karvonen at the University of Minnesota for their comments and guidance as we worked through the collected Amharic data. We would also like to thank Larry Hyman, Sharon Inkelas, and the audiences of two University of Minnesota linguistic colloquia for their comments and suggestions on the subject matter presented here. Most importantly we would like to thank our two Amharic language consultants, Selamawit Ayalkabet and Martha Ashine, for their time, input, and patience throughout the elicitation process. Authors: Hannah Sande, UC Berkeley (sande570@, berkeley.edu) and Andrew Hedding, University of Minnesota (hedd0026@umn.edu).
} 
2. Default stress pattern

a. Two syllables
i. (mät'.fat)
'to vanish'
ii. (do.ro)
'chicken'

b. Three syllables
i. (mät.räf).räf
'to overflow'
ii. (k'o.fi).ja
'hat'

c. Four syllables

$\begin{array}{lll}\text { i. } & \text { (män.k'ä).(sa.k'äs) } & \text { 'to move (your body)' } \\ \text { ii. } & \text { (mäf.k'ä).(da.däm) } & \text { 'to race' } \\ \text { iii. } & \text { (t'ä.rä).(p'e.za) } & \text { 'table' }\end{array}$

d. Five + syllables

i. (as.da).(ka.käl).ku 'I arranged (my schedule)'

ii. (jä.tä).(kä.fä).(ta.win) bir 'the open door'

The default stress system in Amharic is unrelated to whether a syllable is open or closed. The initial syllable is stressed, as is every odd syllable. The final syllable is never stressed. In words with an odd number of syllables, the final syllable remains unstressed, extrametrical.

3.2 GeminATES ATTRACT STRESS. Syllables closed by a geminate consonant attract stress, no matter where these syllables fall within a word. This holds even when it violates CLASH-when there are multiple syllables containing geminates in a row-and NON-FINALITY — when the geminate is in the final syllable.

3. Syllables closed by geminates are always stressed
a. sej.(tot $\left.\int \mathrm{t} \int\right)$ 'women'
b. mä.(t)äm.mär) 'to add an ingredient to something'

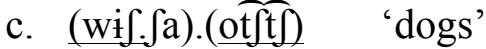

4. CLASH violations

a. (bäl).(lat $\left.\widetilde{t} \cdot \mathrm{tgh}^{\mathrm{w}}\right)$ 'y'all ate'

b. (ij.jä).(tät).(t'al).(lal).(latf. $\widetilde{t} \mathrm{inh}^{\mathrm{w}}$ ) näw 'y'all are hating each other'

c. (läm).(min).(nät.tä).(mam.mä).(näb.bät) 'to the one $(\mathrm{m})$ that we believe in'

5. Non-FINALITY violations

a. (t Ţa.räs).(wall) 'he finished'

b. (tTa.rä).sät5 'she finished'

In a four syllable word ending in a geminate, $\sigma \cdot \sigma . \sigma . \sigma_{\mathrm{G}}$, we'd expect the geminate to be stressed, and then for the default pattern described in 3.1 to hold: $(\sigma . \sigma) \cdot \sigma .\left(\sigma_{\mathrm{G}}\right)$. Instead, we find that all feet are aligned to the final geminate and we get initial lapse: $\sigma \cdot(\sigma . \sigma) .\left(\sigma_{\mathrm{G}}\right)$.

6. Feet align to syllables closed by geminates
a. ji.(säb.ra).(wall)
'he will break (s.thg)'
b. k'o.(fi.ja.)-( $\widetilde{\left.\text { otft } \int\right)}$
'hats'

If there is a geminate in a word, feet align to the syllable containing the geminate, instead of aligning to the left edge of the word as expected by the default stress pattern. When there is more 
than one geminate in the word, all syllables containing geminates are footed first. When no further binary, trochaic feet can be formed, remaining syllables are left unparsed.

7. Foot formation around geminates first
a. tä.(gag.gä).rä.(wal.liț $)$
'she will bake it'
b. i.(fäl.li).ga.(tal.la).hu
'she needs me'

We refer to syllables closed by a geminate as heavy, and we claim that they are bimoraic because they attract stress and other phonological properties (Hyman 1985, and others). Other closed syllables are not bimoraic. The prominence of CVG syllables is demonstrated by the stress pattern in Amharic, and as we will show in the following section, it is also evidenced by adjectival reduplication.

3.3 SuMMARIZING AMHARIC STRESS. The default stress pattern in Amharic can be described as forming left-aligned, trochaic, binary feet with no final stress. Exceptions to this stress pattern occur when geminates are present. Syllables closed by geminates are heavy, attracting stress even if the result is stress clash, a stressed final syllable, or the lack of initial stress. Other closed syllables are not heavy, because they do not attract stress in the same way.

4. Amharic adjectival reduplication. In Amharic, one strategy for pluralization of noun phrases is partial reduplication of an adjective within the noun phrase. Previous literature on Amharic reduplication is minimal. Leslau (1995) notes some adjectives may undergo partial reduplication for pluralization, though he makes no generalization about which words allow this reduplication strategy. Rose (2003) discusses a similar reduplication pattern in verbs, but does not detail adjectival reduplication. Here we detail the adjectival reduplication strategy in Amharic, showing that geminates license this partial reduplication.

4.1 PARTIAl REDUPLICATION FOR PLURALIZATION. Amharic adjectives agree in number with the nouns they modify. Adjectives are normally inflected with a plural suffix with the noun phrase is plural. The noun may also be optionally inflected with the same plural suffix /-ot $\widetilde{f f} /$.

$$
\begin{aligned}
& \text { 8. Default pluralization strategy } \\
& \begin{array}{l}
\text { a. takats sau } \\
\text { lazy person } \\
\text { 'lazy person' }
\end{array} \\
& \text { b. takatf-ot } \int \mathrm{t} \int \text { sau-ot } \widetilde{\mathrm{t} f} \\
& \text { lazy-PL person-PL } \\
& \text { 'lazy people' }
\end{aligned}
$$

Adjectives that contain a geminate can optionally undergo an alternative pluralization strategy: partial reduplication. The geminate consonant itself is reduplicated, and the reduplicated consonant surfaces as a singleton in a new syllable. Syllables that do not contain a geminate do not have the option of the reduplication method of marking pluralization.

9. Geminates license partial reduplication for pluralization

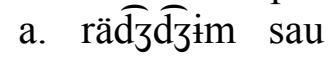

tall person

'tall person' 


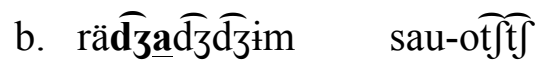
tall.PL
person-PL
'tall person'
c. k'ondzo sau
beautiful person
'beautiful person'

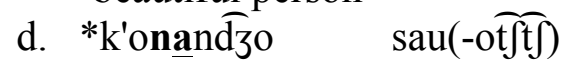

4.2 SUMMARIZING ADJECTIVAL REDUPLICATION. One means of plural agreement between nouns and adjectives involves internal partial reduplication of the adjective. Crucially, this reduplication process is only licensed by syllables closed by geminates. Other syllable codas do not license adjectival reduplication for pluralization. Much the same way that syllables closed by geminates attract stress, they also license reduplication. This serves as evidence that syllables closed by geminates, but not other syllables, are heavy in Amharic.

5. Theoretical implications. Moraic Theory (McCarthy and Prince 1986; Hayes 1989; Ito 1989) and Weight-by-Position (Hayes 1989) predict that there should be languages where geminates but not other codas are moraic, making syllables heavy and attracting stress and other phonological processes. However, this prediction has not, until now, been attested in one of the world's languages (Tranel 1991, Davis 2011). Tranel's (1991) Principle of Equal Weight for Codas claims, "Coda portions of geminate consonants behave in the same way as other coda consonants with respect to syllable weight (1991)." The table below shows the predictions of Moraic Theory and the Principle of Equal Weight for Codas.

\begin{tabular}{llll|} 
[CVG] & [CVC] & Moraic Theory & Principle of Equal Weight for Codas \\
\hline Heavy & Heavy & yes & yes \\
Light & Light & no & yes \\
\hline Heavy & Light & yes & no \\
\hline Light & Heavy & no & no
\end{tabular}

The two theories differ in their predictions about whether a language with heavy CVG but light CVC syllables should exist. Amharic is the first attested example of a language of this sort, supporting the predictions of Moraic Theory and not the Principle of Equal Weight for Codas.

\footnotetext{
References

Davis, Stuart (2011) "Quantity." In John Goldsmith, Jason Riggle and Alan Yu (eds.), The Handbook of Phonological Theory (2nd edition). Oxford: Wiley-Blackwell.

Hayes, Bruce (1989) “Compensatory lengthening in moraic phonology.” Linguistic Inquiry 20.2.

Hudson, Grover (1997) "Amharic and Argobba”. In Robert Hetzron, ed., The Semitic Languages. Routledge.

Hyman, Larry. (1985) A theory of phonological weight. Dordrecht: Foris.

Ito, Junko (1989) "A prosodic theory of epenthesis." Natural language and linguistic theory 7.

Karvonen, Daniel (2005) "Word prosody of Finnish.” Doctoral dissertation, University of California, Santa Cruz. Leslau, Wolf (2000) Introductory Grammar of Amharic. Harrassowitz Verlag

McCarthy, John J. and Alan Prince (1986) "OCP Effects: Gemination and Antigemination." Linguistic Inquiry 17.

Rose, Sharon (2003) "The formation of Ethiopic Semitic internal reduplication." In Joseph Shimron (ed) Language processing and acquisition in languages of Semitic, root-based morphology. Philadelphia: John Benjamins.

Tranel, Bernard (1991) “CVC lights syllables, geminates and Moraic Theory.” Phonology 8.2.
} 